\title{
Effect of Beauveria bassiana on Growth and Bioactivities of Leek Allium porrum
}

\author{
Bulelwa Ntobela, Enoch A. Akinpelu, Ninon G. E. R. Etsassala and Felix Nchu*
}

\begin{abstract}
The mutualistic relationship between endophytic entomopathogenic fungal and their host is well-documented. In this study, effects of colonization of Allium porrum plants by inocula of the endophytic fungus Beauveria bassiana on plant growth and antifungal activities of extracts are reported. The results showed that B. bassiana did not colonize the tissue of leek. While no distinct influence of fungal inoculation on the observed growths of $A$. porrum in terms of number of leaves, aerial part length and dry weight parameters, there was a significant difference in the root fresh weight between control and fungal treatments. We found no significant difference between the control and the fungus treatments in terms of in vitro anti-Fusarium oxysporum and anti- $B$. bassiana activities. Furthermore, the results showed that the acetone extract of the aerial parts of $A$. porrum is bioactive against $B$. bassiana. More extensive studies on the influence of plant antifungal activities on endophytic fungal colonization of plants are warranted.
\end{abstract}

Keywords-Allium porrum, Beauveria bassiana, Fusarium oxysorum, colonization, entomopathogenic.

\section{INTRODUCTION}

Allium species are the most cultivated and consumed vegetable throughout the world $[1,2]$. They can also be used as drugs for human health due to their antimicrobial, lipid lowering, cardiovascular, hypocholesterolemic, antithrombotic, hypoglycemic, anti-tumorigenic activities, as well as antifungal activity for both animal and plant pathogens [3]. Plants of this species are well-known for their rich sources of secondary metabolites with quality biological activities [4]. Like other Allium species, leek extracts contain many bioactive agents, which include organosulfur compounds, phenolic compounds, non-structural, as well as soluble carbohydrates, various amino acids and organic acids [5, 6]. These medicinal plants are a source of many natural extractible metabolites that can be used as pesticides [7]. The compounds may vary according to the plant species. Popular examples of these compounds includes, flavonoids, phenols and phenolic glycosides, unsaturated lactones, sulphur compounds, saponins cyanogenic glycosides and glucosinolates [8-11]. Also, secondary metabolites have disease suppressing properties [12].

Manuscript received August 9, 2020. This work was supported by Cape Peninsula University of Technology, University Research Fund Grant no: R166.

B. Ntobela, E. A. Akinpelu, N. G. E. R. Etsassala, and F. Nchu are with the Department of Horticultural Sciences, Cape Peninsula University of Technology, Bellville Campus, Symphony Way, PO Box 1906, Bellville, 7535, South Africa.
Chemical pesticides and insecticides have been used for many years in agricultural industries to reduce the damage caused by insects and pests; however, these chemicals are harmful to both the environment and human health [13]. With the increasing attention on the negative impacts of chemical/synthetic pesticides on the environment and human health, Allium species could be the sustainable solution to the increasing demand for an ecologically friendly pest control strategy.

The use of medicinal plants and endophytic entomopatogenic fungi have been reported to be effective and that may contribute to the reduction in the use of chemical products in pest control [14]. Many microorganisms inhabit host plant tissues without causing a negative impact [15-18]. For example, endophytic fungi can positively influence plant growth development and secondary metabolites, and provides host plant with protection against pathogens and other contaminants [19-21, 22]. However, the interaction of endophytic fungi and host plant vary from host to host depending on plant and endophyte genotypes [17, 23, 24]. Although much focus have been on endophytic fungal colonization of plants, few studies have specifically investigated the relationship between endophytic fungal colonization of plant tissue and host plants' antifungal activity. Hence, the objective of this study was i) to evaluate the colonization of leek plants (A. porrum) by endophytic fungus $B$. bassiana and ii) the effect of fungal inoculation on growth and anti-fungal activities of acetone extract of leek against $B$. bassiana (a fungal endophyte) and $F$. oxysporum (a phytopathogen).

\section{MATERIALS AND METHODS}

\section{A. Plant Material}

Three weeks old seedlings of Leeks (A. porrum) were obtained from Stodels Pty Ltd. Garden Centre, Cape Town, South Africa. The root soil of the seedlings was washed off under a running tap water. Subsequently, individually seedlings were transplanted into $25 \mathrm{~cm}$ pots filled with different substrate mixes: silica sand $25 \%+$ perlite $25 \%$, cocoa peat $25 \%+$ vermiculite $25 \%$. The experiment was laid out in a Completely Randomized Design (CRD) with 4 treatments and each consisting of 15 replicates, including the control treatment. Plants were hand irrigated with deionized water $(100 \mathrm{~m}$ per pot) once a week and followed by fertilizing with Nutrifeed® (Starke Ayres Pty. Ltd. Cape Town, South Africa) solution (100 ml per pot) at a concentration of $10 \mathrm{~g} / 5 \mathrm{~L}$ after every three days. 


\section{B. Fungus}

Entomopathogenic fungal culture of $B$. bassiana (Meerlust $\mathrm{P} 3 / \mathrm{S} 1$ ) was obtained from the existing cultures in the Horticulture Research Laboratory of Cape Peninsula University of Technology, Bellville campus. Fungal cultures were incubated for 3 weeks in a dark incubation chamber at $25^{\circ} \mathrm{C}$. The fungal culture consisted of Potato Dextrose Agar (PDA) supplemented with Streptomycin Sulfate (Sigma-Aldrich), Streptomyces sp. and Ampicillin sodium salt (Sigma-Aldrich). Mycelium was grown on the PDA in $9 \mathrm{~cm}$ diameter petri-dishes. For preparing media, deionized water was autoclaved for 15 minutes at $121^{\circ} \mathrm{C}$. After the incubation period, conidia were harvested by scraping mycelium from the surface of PDA using a sterile scalpel and placed into a Corning® $50 \mathrm{~mL}$ centrifuge tube with $10 \mathrm{ml}$ of sterile distilled water containing $0.05 \%$ Tween 80 and vortexed for 5 minutes to homogenize the suspension. The conidia concentration was determined using Neubauer haemocytometer with light microscope (400X magnification); the concentration of conidial stock solution was adjusted to $1 \times 10^{7}$ spores $/ \mathrm{ml}$. Serial dilution method was performed to obtain different conidial concentrations as follows: $0,1 \times 10^{5} 1 \times 10^{6}$ and $1 \times 10^{7}$ spores $/ \mathrm{ml}$. Conidial viability was determined by plating the conidial suspension onto potato dextrose agar, incubated at $25^{\circ} \mathrm{C}$ for $18-24$ hours, and conidial germination enumerated at $400 \mathrm{X}$ magnification. Over $90 \%$ of the conidial germination was achieved for the $B$. bassiana isolate used in this study.

\section{Plants Inoculation}

Plants were allowed to establish for a month. Subsequently, they were systematically treated with three different concentrations of B. bassiana conidial suspension as described above. Plants in the control treatment were inoculated with sterile distilled water. Individual plants were drenched with 100 $\mathrm{ml}$ of the different treatments of conidial suspension every 2 weeks. Temperature and humidity was recorded daily. To determine plant growth in response to the different treatments of endophytic fungi, data on number of leaves and plant height were recorded once a week. Plant height was measured from the soil surface to the tip of the aerial part. At the end of the experiment, aerial part fresh weight, root fresh weight (roots were washed to remove soil), and root length were recorded. To determine dry weights, fresh aerial parts and roots were oven-dried at $35{ }^{\circ} \mathrm{C}$ for 7 days before dry weights. The plant growth data collected were analyzed using one-way analysis of variance (ANOVA) and Tukey HSD test was used to separate the means at a level of significance of $\mathrm{P}<0.05$.

\section{Assessment of Colonization}

The colonization of Leek plants by $B$. bassiana was determined after 28 days of inoculation following methods by Teferea and Vidal [25]. Plants were carefully removed from pots, and the roots were washed with running tap water. Sections $(5 \mathrm{~mm} \times 2 \mathrm{~mm})$ of fresh healthy aerial parts and root of plants were cut with sterile blade. The sections were sterilized in $70 \%$ ethanol for 30 sections, and then rinsed in sterilize distilled water for 60 seconds. The sterilized samples (sections) were allowed to dry under the laminar flow cabinet. Five samples from each plant were then placed on a Potato Dextrose Agar (PDA). Afterward, they were incubated in the dark at $25^{\circ} \mathrm{C}$ for 14 days. Mycelial outgrowth from the sections were examined microscopically. The data on fungal colonization of the tissue were expressed as percentage colonization $=100 \times($ number of plant pieces colonized/total number of plant pieces) [26].

\section{E. Tissue analysis}

Leaf samples were analysed for macro- and micro elements by a commercial laboratory Bemlab (Pty.) Ltd. in Somerset West, South Africa. Leaves were washed with Teepol solution, rinsed with deionized water and dried at $70^{\circ} \mathrm{C}$ overnight in an oven. The dried leaves were then milled and ashed at $480^{\circ} \mathrm{C}$ shaken up in a 50:50 $\mathrm{HCl}(50 \%)$ solution for extraction through filter paper (Campbell and Plank, 1998; Miller, 1996). The Potassium (K), Phosphorus (P), calcium (Ca), magnesium $(\mathrm{Mg})$, sodium $(\mathrm{Na})$, manganese $(\mathrm{Mn})$, iron $(\mathrm{Fe})$, copper $(\mathrm{Cu})$, zinc $(\mathrm{Z})$ and boron $(\mathrm{B})$ content of the extracts were analysed using Ash method. Total nitrogen $(\mathrm{N})$ content of the leaves will determined through total combustion in a Leco $\mathrm{N}$-analyser. The amounts of $\mathrm{N}, \mathrm{P}, \mathrm{K}, \mathrm{Ca}$ and $\mathrm{Mg}$ estimated from percentage (\%) to $\mathrm{mg} / \mathrm{kg} ; 10000$ is used as the conversion factor.

\section{F. Material extracts}

Fresh materials of $A$. porrum aerial parts were crushed with a ceramic mortar and pestle for 5 minutes. Extraction was done by transferring $5 \mathrm{~g}$ of crushed plant material into a Corning® 50 $\mathrm{mL}$ centrifuge tube containing $250 \mathrm{ml}$ of aqueous acetone, tightly capped to avoid evaporation of acetone, and vortexed for $5 \mathrm{~min}$ and stored at room temperatures for 22 hours. The supernatant was filtered out with Whatman No. 1 filter paper. The extract was dried for 3 days at room temperature $\left(26 \pm 2{ }^{\circ} \mathrm{C}\right)$ with a fan under a fume hood. The quantity of plant extract obtained was recorded after evaporation of the acetone. Weighed extracts were then mixed with water and aqueous acetone in a ratio of $1: 3$ to obtain a crude extract concentration of $6 \mathrm{mg} / \mathrm{ml}$.

\section{G. Anti-fungal activity}

The micro-dilution method [27] was employed with slight modifications in determining the minimum inhibitory concentration (MIC) for the extracts. A. porrum extracts were diluted into acetone to obtain a starting concentration of 6 $\mathrm{mg} / \mathrm{ml}$. The starting concentration was diluted two fold in each successive serial dilution. Strains of Fusarium oxysporum (MTL 211) and B. bassiana (Meerlust P3/S1) were obtained from existing cultures in the Horticulture Research Laboratory of Cape Peninsula University of Technology, Bellville campus. The $F$. oxysporum and B. bassiana were sub-cultured from stock agar plates and transferred into Nutrient Broth (Merck, South Africa) for four hours. The fungal cultures $(100 \mu \mathrm{l})$ were added to each well of the 96 -well microplates $\left(10^{5}\right.$ cells/ $\left.\mathrm{ml}\right)$. Mancozeb fungicide and Odeon fungicide (Stodels Pty Ltd. Garden Centre, Cape Town, South Africa) were prepared and 
served as positive controls, while acetone served as a negative control. Forty microliter $\left(\begin{array}{llll}40 & \mu \mathrm{l}\end{array}\right)$ of $0.2 \mathrm{mg} / \mathrm{ml}$ of p-iodonitrotetrazolium chloride (INT) (Sigma) dissolved in sterile distilled water was added to each microplate well, sealed in a plastic bag and incubated at $37{ }^{\circ} \mathrm{C}$ and $100 \% \mathrm{RH}$. The MIC values were recorded after 12 and 18 hours. The antifungal bioassay (MIC) consisted of three replicates per treatment.

\section{H. Phytochemical Screening}

The total alkaloid assay was based on the methods described by Fadhil and Reza (2007). Dry material of leek plant (100 mg) was extracted with $10 \mathrm{ml}$ of $60 \%$ ethanol for 2 hours, and after centrifugation at $4000 \mathrm{~g}$ for 10 minutes. The supernatant $(2 \mathrm{~mL})$ and atropine standard $(2 \mathrm{~mL})$ were mixed with $\% \mathrm{ml}$ sodium phosphate buffer and $12 \mathrm{~mL}$ bromocresol green solution. Afterwards, chloroform $(12 \mathrm{~mL})$ was added to the solution and followed by vigorous shaking using a vortex mixer. The absorbance for the test was determined at $417 \mathrm{~nm}$ and the concentration of the sample $(\mathrm{mg} / \mathrm{g})$ was calculated using standard curve of atropine. The total alkaloid content was expressed as mg of $\mathrm{AE} / \mathrm{g}$ of extract.

The total flavonol content was evaluated using quercetin 0,5 , 10, 20, 40, and $80 \mathrm{mg} / \mathrm{L}$ in 95\% ethanol (Sigma-Aldrich, South Africa) as standard. Briefly, crude sample extracts $(12.5 \mu \mathrm{L})$ was mixed with $12.5 \mu \mathrm{L}$ of $0.1 \%$ hydrochloric acid $(\mathrm{HCl})$ (Merck, South Africa) in $95 \%$ ethanol, $225 \mu \mathrm{L} 2 \% \mathrm{HCl}$ and incubated for $30 \mathrm{~min}$ at room temperature. Absorption readings at $360 \mathrm{~nm}$ were taken at $25^{\circ} \mathrm{C}$ temperature (Mazza et al. 1999). Total flavonol content was expressed as mg quercetin equivalent per dry weight ( $\mathrm{mg} \mathrm{QE} / \mathrm{g} \mathrm{dw}$ ).

The total polyphenol content of extract from dry material of leeks were determined with Folin-Ciocalteau assay (Singleton et al. 1999; Swain and Hills, 1959) and adopting methods by Swain and Hills (1959) for using a plate reader. The extract sample $(25 \mu \mathrm{L})$ was mixed with Folin-Ciocalteu reagent (125 $\mu \mathrm{L}$ ) diluted in distilled water (1:10) (Meck, South Africa). Five minutes later, $100 \mu \mathrm{L}(7.5 \%)$ aqueous sodium carbonate $\left(\mathrm{Na}_{2} \mathrm{CO}_{3}\right)$ (Sigma-Aldrich, South Africa) was added to a 96-well microplate. The plates were incubated for 2 hours at room temperature $\left(25 \pm 2{ }^{\circ} \mathrm{C}\right)$ before the reading of absorbance at $765 \mathrm{~nm}$ using Multiskan plate reader (Thermo Electron Corporation, USA). The standard curve was prepared using 0 , $20,50,100,250$ and $500 \mathrm{mg} / \mathrm{L}$ gallic acid in $10 \%$ ethanol and the results were expressed as mg gallic acid equivalents per $\mathrm{g}$ dry weight (mg GAE/g dw).

\section{Statistical analysis}

The experimental data collected were analyzed using one-way analysis of variance (ANOVA) and the Tukey test was used to separate the means at a level of significance, $\mathrm{P}=0.05$. These computations were performed using PAST software [28].

\section{RESULTS}

\section{A. Endophytic tissue colonization of B. bassiana and its effect on the growth of leeks}

Drenching leek with $B$. bassiana at conidial suspensions (1x
$10^{5}, 1 \times 10^{6}$, and $1 \times 10^{7}$ spores $/ \mathrm{ml}$ ) did not result in tissue colonization; $0 \%$ percent fungal colonization was recorded. Generally, exposure to fungi had minimal effects on the fresh and dry weights of aerial parts of leek. However, there were significant differences among treatments in fresh root weight of A. porrum $(\mathrm{df}=3,59 \mathrm{P}<0.01)$. Control treatment was observed to have the smallest fresh root weight, whereas T1 had the highest fresh weight, see Table I.

TABLE I: EFFECT OF ENTOMOPATHOGENIC FUNGUS- AMENDED MEDIUM ON THE GROWTH PARAMETERS OF A. PORRUM AT 10 WEEKS AFTER PLANTING.

\begin{tabular}{|c|c|c|c|c|}
\hline Treatments & Control & T1 & $\mathrm{T} 2$ & T3 \\
\hline $\begin{array}{l}\text { Dry Root } \\
\text { Weight }(\mathrm{g})\end{array}$ & $0.64 \pm 0.08 \mathrm{a}$ & $0.90 \pm 0.17 \mathrm{a}$ & $0.97 \pm 0.13 \mathrm{a}$ & $0.74 \pm 0.11 \mathrm{a}$ \\
\hline $\begin{array}{l}\text { Dry aerial } \\
\text { Weight }(\mathrm{g})\end{array}$ & $3.65 \pm 0.32 \mathrm{a}$ & $4.1 \pm 0.38 \mathrm{a}$ & $3.8 \pm 0.16 \mathrm{a}$ & $3.30 \pm 0.44 \mathrm{a}$ \\
\hline $\begin{array}{l}\text { Fresh root } \\
\text { Weight }(\mathrm{g})\end{array}$ & $6.44 \pm 0.53 \mathrm{~d}$ & $11.58 \pm 0.69 \mathrm{a}$ & $9.92 \pm 0.88 \mathrm{c}$ & $10.47 \pm 0.93 \mathrm{ab}$ \\
\hline $\begin{array}{l}\text { Fresh aerial } \\
\text { Weight }(\mathrm{g})\end{array}$ & $27.90 \pm 1.08 \mathrm{a}$ & $33.56 \pm 1.52 \mathrm{a}$ & $32.29 \pm 2.02 \mathrm{a}$ & $31.34 \pm 1.49 \mathrm{a}$ \\
\hline $\begin{array}{l}\text { Plant height } \\
\text { (cm) }\end{array}$ & $38.23 \pm 1.44 a$ & $43.06 \pm 2.0 \mathrm{a}$ & $41.03 \pm 1.9 \mathrm{a}$ & $41.86 \pm 1.72 \mathrm{a}$ \\
\hline $\begin{array}{l}\text { Number of } \\
\text { leaves }\end{array}$ & $3.53 \pm 0.25 \mathrm{a}$ & $4.13 \pm 0.21 \mathrm{a}$ & $3.8 \pm 0.21 \mathrm{a}$ & $3.6 \pm 0.23 a$ \\
\hline
\end{tabular}

*Means followed by same lowercase letters in the same row are not significantly different following comparison using Tukey test.

\section{B. Macronutrients}

While there were no significant differences in the plant tissue levels of $\mathrm{P}, \mathrm{K}, \mathrm{Ca}, \mathrm{Mg}$ and $\mathrm{Na}$ between fungus and control treatments $(\mathrm{df}=1,7 \quad \mathrm{P} \geq 0.05), \quad \mathrm{N}$ tissue contents varied significantly $(\mathrm{df}=1,7 \mathrm{P} \leq 0.05)$. The $\mathrm{N}$ content obtained was higher in control and significantly lower in $\mathrm{T} 1 \quad(6.5 \pm 0.64$ $\mathrm{mg} / \mathrm{kg}$ ). Nonetheless, higher levels of $\mathrm{P}, \mathrm{K}, \mathrm{Ca}$ and $\mathrm{Na}$ were observed in T1 - Table II.

TABLE II: EFFECT OF ENTOMOPATHOGENIC FUNGUS-AMENDED MEDIUM ON THE MACRONUTRIENT UPTAKE OF A. PORRUM AERIAL PARTS.

\begin{tabular}{lll}
\multicolumn{2}{c}{ THE MACRONUTRIENT UPTAKE OF A. PORRUM AERIAL PARTS. } \\
\hline Nutrients $(\mathrm{mg} / \mathrm{kg})$ & Control & $\begin{array}{l}\mathrm{T} 1\left(1 \times 10^{7}\right. \\
\text { spores } / \mathrm{ml})\end{array}$ \\
\hline $\mathrm{N}$ & $394.25 \pm 9.96 \mathrm{a}$ & $6.5 \pm 0.64 \mathrm{~b}$ \\
$\mathrm{P}$ & $40.75 \pm 2.49 \mathrm{a}$ & $44.25 \pm 1.84 \mathrm{a}$ \\
$\mathrm{K}$ & $628 \pm 34.07 \mathrm{a}$ & $640.25 \pm 24.61 \mathrm{a}$ \\
$\mathrm{Ca}$ & $0.40 \pm 0.02 \mathrm{a}$ & $0.42 \pm 0.1 \mathrm{a}$ \\
$\mathrm{Mg}$ & $0.50 \pm 0.02 \mathrm{a}$ & $0.47 \pm 0.02 \mathrm{a}$ \\
$\mathrm{Na}$ & $2228.75 \pm 401.92 \mathrm{a}$ & $2351.5 \pm 151.98 \mathrm{a}$ \\
\hline *Means followed by same lowercase letters in the same row are not \\
significantly different following comparison using Tukey test.
\end{tabular}

\section{Micronutrients}

Statistically there was a significant difference between treatments of $\mathrm{Cu}$ levels $(\mathrm{df}=1,7 ; \mathrm{P} \leq 0.005)$. The $\mathrm{Cu}$ levels obtained were higher in $\mathrm{T} 1(4.5 \pm 0.64 \mathrm{~g})$ and low in control $(2 \pm 0.57 \mathrm{~g})$. However, there was no significant difference between treatments in tissue $\mathrm{Mn}, \mathrm{Fe}, \mathrm{Zn}$ or $\mathrm{B}$ level $(\mathrm{df}=1,7$; $\mathrm{P} \geq 0.005$ ) (Table III). 
TABLE III: TISSUE NUTRIENT CONTENT (MG/KG) IN AERIAL PARTS OF $A$. PORRUM FOLLOWING EXPOSURE TO THREE CONCENTRATIONS OF $B$. BASSIANA CONIDIAL SUSPENSION AND CONTROL AT AFTER 10 WEEKS'

\begin{tabular}{lll}
\multicolumn{3}{c}{ POST-TREATMENT. } \\
\hline Nutrients $(\mathrm{mg} / \mathrm{kg})$ & Control & $\begin{array}{c}\mathrm{T} 1 \\
\text { spores } / \mathrm{ml})\end{array}$ \\
\hline $\mathrm{Mn}$ & $47 \pm 9.22 \mathrm{a}$ & $55.5 \pm 2.02 \mathrm{~b}$ \\
$\mathrm{Fe}$ & $87.75 \pm 2.2 .78 \mathrm{a}$ & $91.5 \pm 7.27 \mathrm{a}$ \\
$\mathrm{Cu}$ & $2 \pm 0.57 \mathrm{~b}$ & $4.5 \pm 0.64 \mathrm{a}$ \\
$\mathrm{Zn}$ & $22.25 \pm 2.21 \mathrm{a}$ & $26 \pm 0.91 \mathrm{a}$ \\
$\mathrm{B}$ & $34.75 \pm 3.32 \mathrm{a}$ & $38.75 \pm 1.49 \mathrm{a}$ \\
\hline$*$ Means followed by same lowercase letters in the same row are not \\
significantly different.
\end{tabular}

\section{Minimum inhibitory concentration}

Based on the MIC values, acetone extracts of aerial parts from leek plants that were exposed to fungus (treatment T3) performed significantly $(\mathrm{df}=6,62 ; \mathrm{P} \leq 0.05)$ better than the other treatments, including the positive controls, in inhibiting both B. bassiana and F. oxysporum (Table IV).

TABLE IV: MINIMUM INHIBITORY CONCENTRATION OF ACETONE EXTRACTS OBTAINED FROM AERIAL PARTS OF A. PORRUM GROWN IN ENTOMOPATHOGENIC FUNGUS-AMENDED MEDIA AGAINST B. BASSIANA AND F. OXYSPORUM

\begin{tabular}{lll}
\hline \multirow{2}{*}{ Treatments } & \multicolumn{2}{l}{ MIC $(\mathrm{mg} / \mathrm{ml})$ at $12 \mathrm{~h}$} \\
\cline { 2 - 3 } & $0.07 \pm 0.07 \mathrm{ab}$ & $0.13 \pm 0.03 \mathrm{ab}$ \\
Control & $0.09 \pm 1.11 \mathrm{bc}$ & $0.16 \pm 0.02 \mathrm{ab}$ \\
$\mathrm{T} 1\left(1 \times 10^{7}\right.$ spores $\left./ \mathrm{ml}\right)$ & $0.12 \pm 0.01 \mathrm{c}$ & $0.25 \pm 0.07 \mathrm{~b}$ \\
$\mathrm{~T} 2\left(1 \times 10^{6}\right.$ spores $\left./ \mathrm{ml}\right)$, & $0.04 \pm 1.11 \mathrm{a}$ & $0.08 \pm 0.01 \mathrm{a}$ \\
$\mathrm{T} 3\left(1 \times 10^{5}\right.$ spores $\left./ \mathrm{ml}\right)$ & $1.50 \pm 0.00 \mathrm{~d}$ & $1.50 \pm 0.00 \mathrm{~d}$ \\
Mancozeb & $1.50 \pm 0.00 \mathrm{~d}$ & $1.50 \pm 0.00 \mathrm{~d}$ \\
Odeon & $1.50 \pm 0.00 \mathrm{~d}$ & $1.50 \pm 0.00 \mathrm{~d}$ \\
Acetone &
\end{tabular}

*Means followed by same lowercase letters in the same column are not significantly different following comparison using Tukey test. Mancozeb and Odeon are positive treatments while acetone was used as negative treatment.

\section{E. Phytochemical Screening}

Different phytochemical constituents were analysed from dry material of A. porrum aerial parts shown in Table V. There were no significant differences among treatments for all phytochemical constituents that were analysed $(\mathrm{df}=3,15$; $\mathrm{F}=0.5 ; \mathrm{P} \geq 0.05$ ) and all their values showed similarities to each other.

TABLE V: PHYTOCHEMICAL SCREENING OF A. PORRUM DRY AERIAL PARTS EXPOSED TO DIFFERENT $B$. BASSIANA CONIDIA CONCENTRATIONS T1 $\left(1 \times 10^{7}\right)$,

\begin{tabular}{lccc}
\multicolumn{2}{c}{ T2 $\left(1 \times 10^{6}\right), \mathrm{T} 3\left(1 \times 10^{5}\right)$ AND CONTROL (DEIONIZED WATER). } \\
\hline Treatments & $\begin{array}{c}\text { Polyphenol } \\
(\mathrm{mg} \mathrm{GAE} / \mathrm{g})\end{array}$ & $\begin{array}{c}\text { Flavonols } \\
(\mathrm{mg} \mathrm{QE} / \mathrm{g})\end{array}$ & $\begin{array}{c}\text { Alkaloids } \\
(\mathrm{mg} \mathrm{AE} / \mathrm{g})\end{array}$ \\
\hline Control & $6.93 \pm 0.33 \mathrm{a}$ & $3.5 \pm 0.27 \mathrm{a}$ & $2.17 \pm 0.26 \mathrm{a}$ \\
$\mathrm{T} 1$ & $6.6 \pm 0.76 \mathrm{a}$ & $4 \pm 0.39 \mathrm{a}$ & $2.79 \pm 0.18 \mathrm{a}$ \\
$\mathrm{T} 2$ & $6.16 \pm 0.28 \mathrm{a}$ & $3.6 \pm 0.27 \mathrm{a}$ & $2.82 \pm 0.19 \mathrm{a}$ \\
T3 & $6.23 \pm 0.41 \mathrm{a}$ & $3.9 \pm 0.48 \mathrm{a}$ & $2.83 \pm 0.30 \mathrm{a}$ \\
\hline
\end{tabular}

*Means followed by same lowercase letters in the same column are not significantly different following comparison using Tukey test.

\section{DISCUSSION}

Inoculating leek with the endophytic fungus $B$. bassiana did not lead to tissue colonization by the fungus. However, these results are not in agreement with previous findings from studies that inoculated plants using the soil drenching method [29-31]. Many previous studies have shown the ability of this fungus to colonize a wide array of plant species using different inoculation techniques, such as leaf spraying, root dipping, seed immersion, stem injection, mixing of dry conidia with growing potting medium, and vacuum infiltration [32-35]. The failure of the fungal endophyte to establish in the tissue of leek in the current study could be due to inherent characteristics of the fungal isolate used [31], the host species, the plant part evaluated, and the inoculation methods used - these factors could influence tissue colonization by an endophyte [30, 33, 35]. Literature on the influence of host plants' antifungal activities and bioactive constituents on fungal colonization of plants are scarce. Antifungal constituents of host plant could impair endophytic fungal colonization.

There was no distinct difference on the growth of A. porrum in terms of number of leaves, aerial part length and dry weight parameters. However, root fresh weights were significantly difference among the treatments. Many studies have reported that endophytic fungi $B$. bassiana have plant growth enhancing effects [36, 37]. In a paper by Lopez and Sword [38], $B$. bassiana significantly enhanced plant development in cotton plant. On the contrary, findings by Pai and Bushley [32] demonstrated that endophytic fungus can decreas plant growth and production in tomato plants. While there was no significant influence of fungal inoculation on secondary metabolite contents in this study, B. bassiana is known to produce a variety of bioactive secondary metabolites that can inhibit or promote growth [12, 36, 39].

Previous studies have demonstrated that inoculating plants with endophytic fungi $B$. bassiana promotes nutrient absorption [29, 40, 41]. In this study, inoculation of $B$. bassiana using soil drenching method showed a significant increase in the tissue contents of copper $(\mathrm{Cu})$, manganese $(\mathrm{Mn})$, and a decreased nitrogen $(\mathrm{N})$ content in fresh aerial parts of plants exposed to $B$. bassiana conidia. Cartmill et al. [42] reported similar results. In their study, plants inoculated with mycorrhizal fungi had higher $\mathrm{Cu}$ and $\mathrm{Mn}$ content when compared to untreated plants.

Interestingly, our results showed that the lowest MIC value of acetone extracts of $A$. porrum was observed at T3 $(0.04 \pm 1.11$ $\mathrm{mg} / \mathrm{ml}$ ) and was the most bioactive against $B$. bassiana, but it was not statistically different from control $(0.07 \pm 0.07 \mathrm{mg} / \mathrm{ml})$ treatment at 12-hour post treatment (Table III). Overall, the acetone extracts of aerial parts of $A$. porrum was found to be bioactive against $B$. bassiana in the antifungal assay. The acetone extracts of plants exposed to the lowest fungal spore concentration and no spores were the most active against the fungi in the MIC bioassay. Moreover, acetone extracts of the aerial parts of $A$. porrum performed better than the tested positive controls (Mancozeb and Odeon) (Table III). The results suggested that aerial parts of $A$. porrum acetone extracts have fungistatic effects against $B$. bassiana and $F$. oxysporum. The high antifungal activity of leek plants might have prevented the $B$. bassiana conidia from successfully colonizing its tissue. 
Further investigations are warranted to establish whether tissue colonization by fungal endophytes is influenced by secondary metabolite contents of plants.

In the present study, phytochemical investigation of Allium porrum (leeks) revealed the presence of polyphenols, flavonols and alkaloids in the plant extracts. Plants in the genus Allium are rich in phytochemicals and are exploited by agricultural, nutraceutical and pharmaceutical industries [6, 43-45].

\section{CONCLUSION}

Although successful leek tissue colonization by $B$. bassiana was not recorded in this study, we demonstrated that the presence of a fungus in the root region may still influence the plant physiologically in terms of nutrient availability. In nature, some of these entomopathogens are part of the rhizophere microbiome of the plant, and may influence nutrient availability to and absorption by plants; thus, influencing growth and secondary metabolite production in plants. More extensive studies on the influence of plant antifungal activities on endophytic fungal colonization of plants are warranted.

\section{ACKNOWLEDGMENT}

The authors thank the technicians of the Department of Horticultural Sciences, CPUT for their support during the green house experiment.

\section{REFERENCES}

[1]I. Koca, and B. Tasci, "Mineral composition of leek," VII International Symposium on Edible Alliaceae 1143. pp. 147-152,vol., 2015. https://doi.org/10.17660/ActaHortic.2016.1143.21

[2]J. Sorensen, J. Larsen, and I. Jakobsen, "Pre-inoculation with arbuscular mycorrhizal fungi increases early nutrient concentration and growth of field-grown leeks under high productivity conditions," Plant and Soil, vol. 307, no. 1-2, pp. 135-147, 2008 . https://doi.org/10.1007/s11104-008-9591-7

[3]A. K. Ramaiah, and R. K. H. Garampalli, "In vitro antifungal activity of some plant extracts against Fusarium oxysporum f. sp. lycopersici," Asian Journal of Plant Science and Research, vol. 5, no. 1, pp. 22-27, 2015.

[4]G. H. Rizwani, and H. Shareef, "Genus Allium: The potential nutritive and therapeutic source," J. Pharm. Nutr. Sci, vol. 1, pp. 158-163, 2011. https://doi.org/10.6000/1927-5951.2011.01.02.11

[5]F. Bianchini, and H. Vainio, "Allium vegetables and organosulfur compounds: do they help prevent cancer?," Environmental health perspectives, vol. 109, no. 9, pp. 893-902, 2001. https://doi.org/10.1289/ehp.01109893

[6]E. Block, "Recent results in the organosulfur and organoselenium chemistry of genus Allium and Brassica plants," Dietary Phytochemicals in Cancer Prevention and Treatment, pp. 155-169: Springer, 1996. https://doi.org/10.1007/978-1-4613-0399-2_13

[7]M. M. Niyazi, Z. Khan, N. D. Khan, and S. Mular, "Identification, purification and characterization of bioactive compounds present in Bridelia ferruginea and Piper umbellatum," Int Appl Res, vol. 3, no. 1, pp. 557-559, 2016.

[8]K. Mythili, C. Reddy, D. Chamundeeswari, and P. Manna, "Determination of total phenol, alkaloid, flavonoid and tannin in different extracts of Calanthe triplicata," Journal of Pharmacognsoy and Phytochemistry, vol. 2, no. 2, pp. 40-44, 2014.

[9]J. Matejić, A. Džamić, T. Mihajilov-Krstev, V. Ranđelović, Z. Krivošej, and P. Marin, "Total phenolic content, flavonoid concentration, antioxidant and antimicrobial activity of methanol extracts from three Seseli L. taxa," Open Life Sciences, vol. 7, no. 6, pp. 1116-1122, 2012. https://doi.org/10.2478/s11535-012-0094-4
[10] J. Mierziak, K. Kostyn, and A. Kulma, "Flavonoids as important molecules of plant interactions with the environment," Molecules, vol. 19, no. 10, pp. 16240-16265, 2014. https://doi.org/10.3390/molecules191016240

[11] M. Saxena, J. Saxena, R. Nema, D. Singh, and A. Gupta, "Phytochemistry of medicinal plants," Journal of pharmacognosy and phytochemistry, vol. 1, no. 6, 2013.

[12] M. Zaynab, M. Fatima, S. Abbas, Y. Sharif, M. Umair, M. H. Zafar, and K. Bahadar, "Role of secondary metabolites in plant defense against pathogens," Microbial pathogenesis, vol. 124, pp. 198-202, 2018. https://doi.org/10.1016/j.micpath.2018.08.034

[13] E. Lichtfouse, M. Navarrete, P. Debaeke, V. Souchère, C. Alberola, and J. Ménassieu, "Agronomy for sustainable agriculture: a review," Sustainable agriculture, pp. 1-7: Springer, 2009. https://doi.org/10.1007/978-90-481-2666-8_1

[14] B. J. Philogène, C. Regnault-Roger, and C. Vincent, "Biopesticides d'origine végétale: bilan et perspectives," Biopesticides d'origine végétale, 2e édition, Lavoisier Tec \& doc, Paris, France, pp. 1-24, 2008.

[15] C. Glienke-Blanco, C. I. Aguilar-Vildoso, M. L. C. Vieira, P. A. V. Barroso, and J. L. Azevedo, "Genetic variability in the endophytic fungus Guignardia citricarpa isolated from citrus plants," Genetics and Molecular Biology, vol. 25, no. 2, pp. 251-255, 2002. https://doi.org/10.1590/S1415-47572002000200021

[16] B. Zaferanloo, T. D. Quang, S. Daumoo, M. M. Ghorbani, P. J. Mahon, and E. A. Palombo, "Optimization of protease production by endophytic fungus, Alternaria alternata, isolated from an Australian native plant," World Journal of Microbiology and Biotechnology, vol. 30, no. 6, pp. 1755-1762, 2014. https://doi.org/10.1007/s11274-014-1598-z

[17] S. H. Faeth, and W. F. Fagan, "Fungal endophytes: common host plant symbionts but uncommon mutualists," Integrative and Comparative Biology, vol. 42, no. 2, pp. 360-368, 2002. https://doi.org/10.1093/icb/42.2.360

[18] L.-X. Zhao, L.-H. Xu, and C.-L. Jiang, "Methods for the study of endophytic microorganisms from traditional Chinese medicine plants," Methods in enzymology, pp. 3-21: Elsevier, 2012. https://doi.org/10.1016/B978-0-12-404634-4.00001-2

[19] M. Jia, L. Chen, H.-L. Xin, C.-J. Zheng, K. Rahman, T. Han, and L.-P. Qin, "A friendly relationship between endophytic fungi and medicinal plants: a systematic review," Frontiers in microbiology, vol. 7, pp. 906, 2016. https://doi.org/10.3389/fmicb.2016.00906

[20] W. L. Araújo, P. T. Lacava, F. D. Andreote, and J. L. Azevedo, "Interaction between endophytes and plant host: biotechnological aspects," Plant-microbe interactions, vol. 1, pp. 1-21, 2008.

[21] Y. Wang, and C.-C. Dai, "Endophytes: a potential resource for biosynthesis, biotransformation, and biodegradation," Annals of Microbiology, vol. 61, no. 2, pp. 207-215, 2011. https://doi.org/10.1007/s13213-010-0120-6

[22] C.-h. Ding, Q.-B. Wang, S. Guo, and Z.-y. Wang, "The improvement of bioactive secondary metabolites accumulation in Rumex gmelini Turcz through co-culture with endophytic fungi," brazilian journal of microbiology, vol. 49, no. 2, pp. 362-369, 2018. https://doi.org/10.1016/j.bjm.2017.04.013

[23] J. G. Boursnell, "The symbiotic seed-borne fungus in the cistaceae: i. distribution and function of the fungus in the seeding and in the tissues of the mature plant," Annals of Botany, vol. 14, no. 54, pp. 217-243, 1950. https://doi.org/10.1093/oxfordjournals.aob.a083244

[24] K. Saikkonen, S. H. Faeth, M. Helander, and T. Sullivan, "Fungal endophytes: a continuum of interactions with host plants," Annual review of Ecology and Systematics, vol. 29, no. 1, pp. 319-343, 1998. https://doi.org/10.1146/annurev.ecolsys.29.1.319

[25] T. Tefera, and S. Vidal, "Effect of inoculation method and plant growth medium on endophytic colonization of sorghum by the entomopathogenic fungus Beauveria bassiana," BioControl, vol. 54, no. 5, pp. 663-669, 2009. https://doi.org/10.1007/s10526-009-9216-y

[26] O. Petrini, and P. Fisher, "Fungal endophytes in Salicornia perennis," Transactions of the British Mycological Society, vol. 87, no. 4, pp. 647-651, 1986. https://doi.org/10.1016/S0007-1536(86)80109-7 
[27] F. Nchu, M. A. Aderogba, L. K. Mdee, and J. N. Eloff, "Isolation of anti-Candida albicans compounds from Markhamia obtusifolia (Baker) Sprague (Bignoniaceae)," South African Journal of Botany, vol. 76, no. 1, pp. 54-57, 2010 https://doi.org/10.1016/j.sajb.2009.07.003

[28] Ø. Hammer, D. A. Harper, and P. D. Ryan, "PAST: Paleontological statistics software package for education and data analysis," Palaeontologia electronica, vol. 4, no. 1, pp. 9, 2001.

[29] S. K. Dara, S. R. Dara, and S. S. Dara, "Endophytic colonization and pest management potential of Beauveria bassiana in strawberries," Journal of Berry Research, vol. 3, pp. 203-211, 2013. https://doi.org/10.3233/JBR-130058

[30] S. Parsa, V. Ortiz, and F. E. Vega, "Establishing fungal entomopathogens as endophytes: towards endophytic biological control," JoVE (Journal of Visualized Experiments), no. 74, pp. e50360, 2013. https://doi.org/10.3791/50360

[31] F. Posada, M. C. Aime, S. W. Peterson, S. A. Rehner, and F. E. Vega, "Inoculation of coffee plants with the fungal entomopathogen Beauveria bassiana (Ascomycota: Hypocreales)," Mycological research, vol. 111, no. 6, pp. 748-757, 2007. https://doi.org/10.1016/j.mycres.2007.03.006

[32] S. Pai, and K. Bushley, "Evaluation of Endophytic Beauvaria bassiana as a Targeted Insecticide in Tomato," U. o. Minnesota, ed., 2015.

[33] A. M. Muvea, R. Meyhöfer, S. Subramanian, H.-M. Poehling, S. Ekesi, and N. K. Maniania, "Colonization of onions by endophytic fungi and their impacts on the biology of Thrips tabaci," PloS one, vol. 9, no. 9, pp. e108242, 2014. https://doi.org/10.1371/journal.pone.0108242

[34] N. Allegrucci, M. S. Velazquez, M. L. Russo, M. E. Pérez, and A. C. Scorsetti, "Endophytic colonisation of tomato by the entomopathogenic fungus Beauveria bassiana: the use of different inoculation techniques and their effects on the tomato leafminer Tuta absoluta (Lepidoptera: Gelechiidae)," 2017. https://doi.org/10.1515/jppr-2017-0045

[35] M. L. Russo, S. A. Pelizza, M. N. Cabello, S. A. Stenglein, and A. C. Scorsetti, "Endophytic colonisation of tobacco, corn, wheat and soybeans by the fungal entomopathogen Beauveria bassiana (Ascomycota, Hypocreales)," Biocontrol Science and Technology, vol. 25, no. 4, pp. 475-480, 2015. https://doi.org/10.1080/09583157.2014.982511

[36] P. Gurulingappa, G. A. Sword, G. Murdoch, and P. A. McGee, "Colonization of crop plants by fungal entomopathogens and their effects on two insect pests when in planta," Biological control, vol. 55, no. 1, pp. $34-41,2010$ https://doi.org/10.1016/j.biocontrol.2010.06.011

[37] L. R. Jaber, and J. Enkerli, "Effect of seed treatment duration on growth and colonization of Vicia faba by endophytic Beauveria bassiana and Metarhizium brunneum," Biological Control, vol. 103, pp. 187-195, 2016. https://doi.org/10.1016/j.biocontrol.2016.09.008

[38] D. C. Lopez, and G. A. Sword, "The endophytic fungal entomopathogens Beauveria bassiana and Purpureocillium lilacinum enhance the growth of cultivated cotton (Gossypium hirsutum) and negatively affect survival of the cotton bollworm (Helicoverpa zea)," Biological Control, vol. 89, pp. 53-60, 2015. https://doi.org/10.1016/j.biocontrol.2015.03.010

[39] A. F. Sahab, "Antimicrobial efficacy of secondary metabolites of Beauveria bassiana against selected bacteria and phytopathogenic fungi," J. Appl. Sci. Res, vol. 8, no. 3, pp. 1441-1444, 2012.

[40] S. Raya-Díaz, A. R. Sánchez-Rodríguez, J. M. Segura-Fernández, M. d. C. del Campillo, and E. Quesada-Moraga, "Entomopathogenic fungi-based mechanisms for improved Fe nutrition in sorghum plants grown on calcareous substrates," PloS one, vol. 12, no. 10, pp. e0185903, 2017. https://doi.org/10.1371/journal.pone.0185903

[41] M. Mishra, R. Prasad, and A. Varma, "Endophytic fungi: biodiversity and functions," Int J Pharm Bio Sci, vol. 6, no. 1, pp. 18-36, 2015.

[42] A. D. Cartmill, L. A. Valdez-Aguilar, D. L. Bryan, and A. Alarcón, "Arbuscular mycorrhizal fungi enhance tolerance of vinca to high alkalinity in irrigation water," Scientia Horticulturae, vol. 115, no. 3, pp. 275-284, 2008/02/01/, 2008.

https://doi.org/10.1016/j.scienta.2007.08.019
[43] P. García-Herrera, P. Morales, V. Fernández-Ruiz, M. C. Sánchez-Mata, M. Cámara, A. M. Carvalho, I. C. Ferreira, M. Pardo-de-Santayana, M. Molina, and J. Tardío, "Nutrients, phytochemicals and antioxidant activity in wild populations of Allium ampeloprasum L., a valuable underutilized vegetable," Food research international, vol. 62, pp. 272-279, 2014 https://doi.org/10.1016/j.foodres.2014.03.004

[44] K. H. Kyung, "Antimicrobial properties of allium species," Current opinion in biotechnology, vol. 23, no. 2, pp. 142-147, 2012. https://doi.org/10.1016/j.copbio.2011.08.004

[45] M. Olusanmi, and J. Amadi, "Studies on the antimicrobial properties and phytochemical screening of garlic (Allium sativum) extracts," Ethnobotanical leaflets, vol. 2009, no. 9, pp. 1186-1196, 2010.

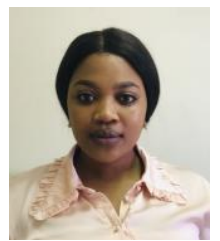

Bulelwa Ntobela was born and raised in Queenstown, Eastern Cape. She holds a Baccalaureus Technologiae and National Diploma in Horticulture, obtained from Cape Peninsula University of Technology. Bulelwa is currently a Master student in the Department of Horticultural Sciences, Cape Peninsula University of Technology in Cape Town, Western Cape. Her research interests include plant physiology, plant cultivation and biological control of insects. Bulelwa is registered with South African Council for Natural Scientific Professions (SACNASP) as a Natural Scientist Candidate. She completed an internship programme offered by National Research Foundation, South Africa that was hosted by the Department of Horticultural Sciences, Cape Penisnula University of Technology. She had served as a research laboratory assistant, and was closely working with undergraduates and postgraduates. She is also a tutor and a mentor for undergraduate students. Bulelwa is looking forward to furthering her studies to a $\mathrm{PhD}$ level. 